\title{
Nitrogen Transfer Play an Important Role of Differentially Expressed Protein of Roots in Eucalyptus Urophylla $\times$ E. grandis and Dalbergia Odorifera Nursery Seedlings Intercropping System
}

\author{
Xianyu Yao \\ College of Forestry, Guangxi University \\ Liangning Liao \\ College of Forestry, Guangxi University \\ Yongzhen Huang \\ College of Forestry, Guangxi University \\ Ge Fan \\ College of Forestry, Guangxi University \\ Mei Yang \\ College of Forestry, Guangxi University \\ Shaoming Ye ( $\nabla$ yshaoming@163.com ) \\ College of Forestry, Guangxi University
}

Research article

Keywords: Eucalyptus urophylla × E. grandis, Dalbergia odorifera, Rhizosphere interaction, Nitrogen uptake, Nitrogen transfer, Differentially expressed proteins

Posted Date: November 17th, 2020

DOI: https://doi.org/10.21203/rs.3.rs-105435/v1

License: (c) (i) This work is licensed under a Creative Commons Attribution 4.0 International License. Read Full License 


\section{Abstract}

Background: The mixing of Eucalyptus with $\mathrm{N}_{2}$-fixing trees is a frequently successful and sustainable cropping practice. In this study, we evaluated nitrogen transfer and conducted a proteomic analysis on seedlings of Eucalyptus and a $\mathrm{N}_{2}$-fixing tree, Dalbergia (D.) odorifera, from intercropping and monocropping systems, to elucidate the physiological effecting and the molecular mechanisms on $\mathrm{N}$ transfer of Eucalyptus mixed with D. odorifera.

Results: We demonstrated the following: (1) Nitrogen transfer occurred from D. odorifera to E. urophylla $\times$ E. grandis by $14.6 \%$. Interspecific facilitation of $\mathrm{N}$ uptake and root growth in $E$. urophylla $\times$ E. grandis was increased in the intercropping system, but the root growth and $\mathrm{N}$ absorption of $D$. odorifera were inhibited. (2) Among differentially expressed proteins was greater than 1.5 times, E. urophylla $\times$ E. grandis were found to be up-regulated several proteins for the nitrogen assimilation and enhancing the nitrogen competition, such as the proteins related to tricarboxylic acid/organic transformation, nitrogen metabolism and nitrogen assimilation; it also up-regulated the expression of stress resistant protein for its adaptability. However, the assimilation and metabolism of nitrogen was promoted in D. odorifera through the up-regulation of amino acid metabolism related proteins, and increased the key enzyme abundance of glycolysis pathway in D. odorifera. (3) Importantly, E. urophylla $\times$ E. grandis was the beneficiary in the process of $\mathrm{N}$ transfer, there were more different proteins involved in the synthesis pathway than that of the metabolic pathway, but there were more functional proteins involved in metabolic degradation in $D$. odorifera. Additionaly, the two groups of nitrogen compound transporter were found in $E$. urophylla $\times E$. grandis, i.e. the molecular mechanism of the $\mathrm{N}$ transfer from $D$. odorifera to $E$. urophylla $\times$ E. grandis was explained by proteomics.

Conclusions: Our study suggests that $\mathrm{N}$ transfer occurred from $D$. odorifera to $E$. urophylla $\times$ E. grandis and it was affected by the variations in the differentially expressed protein. We anticipate the result can be verified in field experiments for the sustainable development of Eucalyptus plantations.

\section{Background}

According to the Millennium Ecosystem Assessment, forest plantations represent only $5 \%$ of the total forest area, but they fulfill more than one-third of the global demand for wood products, an amount anticipated to increase sharply in the next decades [1]. Eucalyptus is widely planted in the tropics and subtropics and is one of the most important fast-growing trees for the pulp and paper as well as the biorefinery industries [2], not only in subtropical China but also throughout the world. This tree covers 4.6 million hectares in China [3]. While Eucalyptus is considered to have high commercial value, its drawbacks include high nutrient exportation and depletion of $\mathrm{N}$ and $\mathrm{P}$ stocks with successive rotations, further, decrease productivity [4]. It is precisely that $\mathrm{N}$ availability is often a factor limiting eucalypt growth [5], additional $\mathrm{N}$ input may be required to ensure high and sustainable stand production. Therefore, fertilizers are often used in commercial eucalypt plantations, but the utilization rate of exogenous $\mathrm{N}$ is very low and only approximately $30 \%$ [6]. High levels of $\mathrm{N}$ exported during harvesting every $6-7$ years 
have led to concerns about their economic sustainability, and current silvicultural practices lead to higher $\mathrm{N}$ outputs than the $\mathrm{N}$ inputs in most commercial plantations [7], which can be expensive and potentially contribute to water eutrophication or other types of pollution [8-9]. Ecological mechanisms that occur in natural ecosystems to sustain productivity should be utilized [10], and the slight reduction in productivity could be worth the reduced fertilizer costs if the difficulties in implementing mixed-species plantations are overcome by forest managers $[1,9]$.

Introducing legume trees into Eucalyptus plantations might be an attractive option for sustaining high yields [11], combining ecological processes of facilitation between $\mathrm{N}_{2}$-fixing tree species (NFT) and non$\mathrm{N}_{2}$-fixing tree species (non-NFT) with large $\mathrm{N}$ inputs resulting from biological fixation of atmospheric $\mathrm{N}_{2}$ $[8,9]$, and this strategy may be a promising way to balance the soil $\mathrm{N}$ budget and improve soil $\mathrm{N}$ availability through $\mathrm{N}_{2}$ fixation and $\mathrm{N}$ recycling [12]. Various experiments have shown that mixed-species plantations of eucalypts with NFT have the potential to increase stand productivity when compared to eucalypt monoculture [1,13-14]. The positive interactions may help enhance stand productivity in mixedspecies plantations with NFT $[1,3,15]$, and complementarity, which results in differences in resource requirements between the species in the mixture when interspecific competition is lower than intraspecific competition, leads to improved use of the available resources at the stand level [16]. $\mathrm{N}$ fixation by NFS is supposed to improve soil $\mathrm{N}$ availability, alleviating $\mathrm{N}$ limitation and facilitating the growth of the target species in N-limited soils $[9,17]$. The mixing of Eucalyptus and $\mathrm{N}_{2}$-fixing species changes the $\mathrm{N}$ utilization mechanism mainly through $\mathrm{N}$ transfer, and $\mathrm{N}$ derived from the atmosphere can become rapidly available to non-NFT through root exudation or by direct transfer through common mycorrhizal networks [18]. Eucalyptus was the dominant species, absorbing large amounts of $\mathrm{N}$ and reducing soil $\mathrm{N}$ content, i.e., soil $\mathrm{N}$ availability was lower and the $\mathrm{N}$ fixation efficiency of legumes was higher in intercropping systems than in monocultures and resulting from less $\mathrm{N}$ application $[3,11,19]$. However, other studies have shown no impact, or a depressive effect, of mixtures on eucalypt growth [20], i.e., mixed-species stands are sometimes less productive than target species in monoculture [4]. Even when mixed-species plantations that include an NFT component do not increase total biomass production, they are likely to provide other benefits, such as increased organic matter storage and mineral $\mathrm{N}$ availability in the upper soil layers, reduced risk of pest damage, and an increased range of products [21]. All these data are key points for understanding the conditions that are required so that mixed-species plantations will perform out eucalypt monocultures in terms of wood production.

Most studies have described that the $\mathrm{N}$ transfer acted on the patterns of tree growth, plant biomass, nutrient content, biological $\mathrm{N}$ fixation and soil physical-chemical properties in monoculture and intercropped plantations of Eucalyptus and $\mathrm{N}_{2}$-fixing tree species $[1,3,11]$. While these studies illustrate the advantage of mixed forest systems, they also raise many questions regarding the molecular mechanisms of root interactions. Nevertheless, studies on the molecular mechanisms of root interactions in the mixed system of Eucalyptus and $\mathrm{N}_{2}$-fixing species are lacking, and a change in plant root molecular structure is crucial for the sustainable growth of plant physiological metabolism in the forestry system 
and indirectly affects plant biological yield. Therefore, elucidating the molecular mechanisms of root development and function is important for improving plant productivity [22].

Over the past decade, management has been shown to affect subsoil root activity, and proteomics is the main tool to solve biological or abiotic, physiological and biochemical problems for plants [23]. However, most studies have reported the root morphological responses to a heterogeneous nutrient supply and to flooding [24] or responses to environmental stresses [25-26], such as iron sufficiency/deficiency conditions [27] and $\mathrm{N}$ nutrition stress [28], drought stress [29] and temperature variations [30] etc., are the major factor affecting physiological metabolism of the root system. Proteomic strategies have become powerful tools that [31], when combined with complementary molecular genetic and physiological analyses, can provide a framework for understanding the molecular basis of complex biological processes [32]. Interestingly, a few studies of the roots molecular mechanisms have reported in intercropping systems, such as the maize/peanuts [33] and bean (Vicia faba)/maize [34] intercropping systems. In particular, proteomic studies on the root interactions in the NFT and Eucalyptus mixed plantation are lacking, as it is difficult to address ecological problems in a mixed system of woody plants. Thus, we hypothesized that the yield of the mixed Eucalyptus and NFT was also affected by the differentially expressed proteins.

E. urophylla $\times$ E. grandis and an NFT, Dalbergia odorifera, grown in an intercropping vs. monoculture system were used in our study. The differences between intercropping and monoculture treatments of the two species were found to result from rhizosphere effects. For elucidation of the molecular basis of the $E$. urophylla $\times E$. grandis and $D$. odorifera intercropping system, the two species were planted in the same soil conditions. TMT/iTRAQ labeling was used to detect the expression levels of several $\mathrm{N}$ metabolism genes in the roots of the two species grown in different planting systems. The aims of the experiments were (1) to verify the competitive advantages of the two species with regard to $\mathrm{N}$ absorption and $\mathrm{N}$ transfer in the intercropping system; (2) to identify the correlation between different functional protein groups and physiological metabolism of the two species in the intercropping system; (3) to analyze the effect of $\mathrm{N}$ transfer on the expression of proteins involved in synthetic and metabolic pathways.

\section{Results}

\section{Root morphology, $\mathbf{N}$ uptake and $\mathbf{N}$ transfer}

We investigated the relationship between $\mathrm{N}$ uptake and the growth and development of $E$. urophylla $\times E$. grandis and $D$. odorifera roots. The total length, surface area, biomass and $\mathrm{N}$ content of the root samples were also measured. The results showed that monoculture was the most important limiting factor of $E$. urophylla $\times E$. grandis. The root length, surface area, dry matter accumulation and $\mathrm{N}$ uptake significantly improved by $25.93 \%, 18.22 \%, 45.09 \%$ and $75.19 \%$, respectively, due to the rhizosphere effects. Nevertheless, these parameters decreased by $11.12 \%, 11.42 \%, 26.43 \%$ and $28.48 \%$ in D. odorifera, respectively. Thus, the aboveground and belowground ratio of the intercropping $E$. urophylla $\times E$. grandis was less than that of the monoculture, but $D$. odorifera showed the opposite results. In other words, the 
aboveground and belowground ratio was changed because of the low $\mathrm{N}$ content of the two species (inverse ratio). This finding indicated that rhizosphere effects improved the growth and development of $E$. urophylla $\times E$. grandis roots in our intercropping system but limited the development of $D$. odorifera roots (Fig. 1).

The ${ }^{15} \mathrm{~N}$ atom\% was measured in E. urophylla $\times$ E. grandis and D. odorifera (Fig. 2A), i.e. $\mathrm{N}$ transfer occurred from D. odorifera to E. urophylla $\times$ E. grandis. The percentage of $\mathrm{N}$ transfer $(\% \mathrm{NT})$ was $14.61 \%$, which was equal to $150.62 \mathrm{mg} \mathrm{N}$ transfer from D. odorifera to E. urophylla $\times$ E. grandis (Fig. 2C and D).

\section{Proteomic analysis revealed differentially expressed proteins}

The RSD of the two species was approximately 0.05 , which shows that our trial replication was effective (Fig. 3). In this study, a protein was considered differentially expressed when the protein had both a log2fold change of more than 1.5 and a p-value of less than 0.05 . Based on the two criteria, 285 groups differentially expressed proteins (mon/inter) were detected in E. urophylla $\times$ E. grandis roots, 154 groups (54.04\%) of which displayed increased abundance and 131 groups $(45.96 \%)$ of which displayed decreased abundance. In D. odorifera roots, we identified 67 groups $(29.39 \%)$ up-regulated and 221 groups $(70.61 \%)$ down-regulated proteins (Table 1$)$. These results showed that the intercropping and monoculture systems had different proteomic profiles (see Table S1 and Table S2).

Table 1

Differentially expressed protein summary of E. urophylla $\times$ E. grandis/D. odorifera (Filtered with the threshold values of the expression fold change and P-value $<0.05$ )

\begin{tabular}{|c|c|c|c|c|c|c|}
\hline Tree species & $\begin{array}{l}\text { Total } \\
\text { spectrums }\end{array}$ & $\begin{array}{l}\text { Identified } \\
\text { proteins }\end{array}$ & $\begin{array}{l}\text { Quantifiable } \\
\text { proteins }\end{array}$ & $\begin{array}{l}\text { Compare } \\
\text { group }\end{array}$ & $\begin{array}{l}\text { Regulated } \\
\text { type }\end{array}$ & $\begin{array}{l}\text { Fold } \\
\text { change > } \\
1.5\end{array}$ \\
\hline \multirow[t]{2}{*}{$\begin{array}{l}\text { E. urophyllax } \\
\text { E. grandis }\end{array}$} & 254765 & 5246 & 4414 & $\begin{array}{l}\text { Mo-E/In- } \\
\mathrm{E}\end{array}$ & $\begin{array}{l}\text { up- } \\
\text { regulated }\end{array}$ & 154 \\
\hline & & & & & $\begin{array}{l}\text { down- } \\
\text { regulated }\end{array}$ & 131 \\
\hline \multirow[t]{2}{*}{ D. odorifera } & 224342 & 5005 & 4136 & $\begin{array}{l}\text { Mo-D/In- } \\
\text { D }\end{array}$ & $\begin{array}{l}\text { up- } \\
\text { regulated }\end{array}$ & 67 \\
\hline & & & & & $\begin{array}{l}\text { down- } \\
\text { regulated }\end{array}$ & 221 \\
\hline
\end{tabular}

\section{Functional enrichment of the differentially quantified proteins}

The 1.5-fold differential proteins were related to biosynthesis, stress and defense responses, carbohydrate and energy metabolism, nucleic acid metabolism, protein metabolism cell transport, 
biological regulation and signal transduction, cell wall and cytoskeleton metabolism, jasmonic acid (JA) biosynthesis and others (Fig. 4).

After the proteins were assigned to different categories, and then the quantities were calculated via the log10 ( $p$-value) method (Fig. 5). For monocropping vs. intercropping of E. urophylla $\times E$. grandis, the difference in protein content varied from 1.51 for glutamate-ammonia ligase activity to 10.79 for response to biotic stimulus. Nevertheless, for $D$. odorifera, the difference in protein content varied from 1.33 for envelope to 3.87 for protein domain-specific binding. These results indicated that the number of stress proteins increased in the E. urophylla $\times E$. grandis monoculture treatment ,. In addition, the number of responses to stress or stimulus proteins for E. urophylla $\times E$. grandis was greater than that for $D$. odorifera.

\section{KEGG pathway analysis of the differentially quantified proteins}

KEGG database information was used to analyze the biological pathways linked to the differentially expressed proteins in the two species. Four pathways were identified for E. urophylla $\times$ E. grandis, e.g., Ribosome (13 groups of proteins, $p<0.05$ ), Phenylpropanoid biosynthesis (9 groups of proteins), Starch and sucrose metabolism (6 groups of proteins) and Sesquiterpenoid and triterpenoid biosynthesis ( 2 groups of proteins). However, six pathways were identified for $D$. odorifera: Spliceosome (10 groups of proteins), Flavonoid biosynthesis (4 groups of proteins), Glycosphingolipid biosynthesis-globo and isoglobo series ( 2 groups of proteins), Ubiquitin-mediated proteolysis (4 groups of proteins), Fatty acid degradation (4 groups of proteins), and Protein processing in the endoplasmic reticulum (8 groups of proteins). Our results indicated that the main function of $E$. urophylla $\times E$. grandis was synthesis and that of $D$. odorifera was metabolism (Fig. 6).

The quantities were calculated via the -log10 (p-value) method, similar to the functional enrichment. For monocropping vs. intercropping of E. urophylla $\times E$. grandis, the protein abundance of sucrose metabolism, metabolism, ribosome, triterpenoid biosynthesis, B6 metabolism, and aspartate and glutamate metabolism was significantly increased. Nevertheless, $D$. odorifera showed different results, as acid degradation, mediated proteolysis, processing in the endoplasmic reticulum, polymerase, biosynthesis-globo and isoglobo series, spliceosome, and secondary metabolism pathways were significantly enriched (Fig. 7).

\section{LC-MS/MS analysis of genes for some differentially expressed proteins}

To evaluate the correlation between different protein levels, 8 histones were validated by LC-MS/MS analysis (E. urophylla $\times$ E. grandis: A0A059AL91, A0A059BJR3, A0A059BMH2, and A0A059DEJ5; D. odorifera: TRINITY_DN34877, TRINITY_DN31489, TRINITY_DN39873 and TRINITY_ 
DN49158) (Fig. 8). For the two different tree species, the gene expression levels of the four groups were well matched. The ratio of the root down-regulated protein groups was decreased, as shown by LCMS/MS analysis, but was increased in the up-regulated protein groups. The difference between gene expression level and protein abundance may be caused by post-translational modifications (PTMs).

\section{Discussion}

\section{$\mathrm{N}$ transfer occurred in the E. urophylla $\times \mathrm{E}$. grandis/ D. odorifera intercropping system}

Effective utilization of nutrients is one of the two major advantages in legume/non-legume intercropping systems [35]. This process mainly depends on the ability of the root to acquire external resources for plant survival in different environments and adapt to external disturbances [36], which increases the abundance of $\mathrm{N}$ metabolic proteins, such as glutamate dehydrogenase (GDH) and glutamine synthetase nodule isozyme (GS), by the rhizosphere effect [34]. In this study, our results showed that interspecific rhizosphere effects significantly improved $\mathrm{N}$ uptake and promoted the development of $E$. urophylla $\times E$. grandis roots. This finding was consistent with previous studies, indicating that planting NFT might be an attractive option for maintaining the $\mathrm{N}$ fertility of soils with Eucalyptus [4,37]. Nevertheless, the effect on $D$. odorifera in the intercropping systems was limited, possibly because the root exudates of $E$. urophylla $\times E$. grandis had an allelopathic effect on $D$. odorifera. In addition, it may also be caused by $\mathrm{N}$ transfer, which was consistent with previous studies $[3,15]$. In our study, $\mathrm{N}$ transfer occurred from $D$. odorifera to $E$. urophylla $\times$ E. grandis by $14.61 \%$, which was equal to enhancement $150.62 \mathrm{mg} \mathrm{N}$ to $E$. urophylla $\times$. grandis (Fig. 2). The transfer $\mathrm{N}$ was the key $\mathrm{N}$ resource for $E$. urophylla $\times E$. grandis and increased the biomass by $45.09 \%$, i.e., increased $\mathrm{N}$ content significantly improved seedling physiological performance by increasing plant growth and nutrient storage reserves for subsequent root growth [38].

\section{Different stress responses between the two varieties}

Comparative proteomics are frequently used to investigate stress-responsive mechanisms in plants [39]. Intercropping may be more effective at decreasing diseases and enhancing disease suppression than monocropping $[35,40]$. Our proteomic study indicated that most stress- and defense-related proteins increased in E. urophylla $\times$ E. grandis roots in the monocropping system to response oxidative stress, with significant differences in the abundance of proteins related to a series of biological functional processes, including response to biotic stimulus, defense response, response to stress, response to stimulus, etc.

(Fig. 5), which was consistent with previous study, i.e., introduction NFT increased the anti-pressure ability of Eucalyptus [14]. The root character and the molecular structure were altered due to the different microbial community composition in Eucalyptus/NFT plantations [41]. In our study, the ecological advantage of $E$. urophylla $\times E$. grandis was increased by mixture, and biological resistance was altered by regulating the ratio of oxidase and pathogenic proteins, which affected the defense proteins or pathological proteins. The E. urophylla $\times$ E. grandis abundance of the major allergen, peroxidase and 
peroxiredoxin proteins was significantly increased in the intercropping system. The peroxidase 15-like (id: TRINITY_DN22413) of D. odorifera was up-regulated, but peroxidase 4-like (id: TRINITY_DN34591) and nodulin-13-like isoform X1 (id: TRINITY_DN40711) were down-regulated in the intercropping system (Table S2). Peroxidase up-regulated by rhizosphere effects not only prevented active injury but also degraded auxin (probable indole-3-acetic acid-amido synthetase GH3.1 IAA) and reactive oxygen species (ROS) [34]. These changes further promoted the hormone system to rebalance and regulate the formation of adventitious roots and lateral roots to adapt to environmental stresses [42]. Peroxidases such as major allergen, peroxidase, peroxidoredoxins and chloroplastic peroxiredoxin Q were highly abundant in intercropping E. urophylla $\times E$. grandis, indicating that the stress response of plants to external stress was improved by the intercropping system. However, peroxidase 4-like (TRINITY_DN34591) and nodulin-13like isoform X1 (TRINITY_DN40711) were down-regulated in intercropping $D$. odorifera, which may also indicate restricting effects on $D$. odorifera in the intercropping system. Additionaly, when plants were placed in a stressful environment, ascorbic acid was required to regulate the $\mathrm{H}_{2} \mathrm{O}_{2}$ content in plants to improve their stress resistance [43]. While the nucleobase-ascorbate transporter (A0A059CYL1) of $E$. urophylla $\times$ E. grandis showed a higher abundance after monocropping.

In E. urophylla $\times$ E. grandis roots, glutathione S-transferase (GST) (id: A0A059AX10) and the homolog glutathione S-transferase U25 (A0A058ZUA9) were increased after intercropping (Table S1). GST, which catalyzes the conjugation of glutathione to electrophilic substrates, plays a crucial role in cell detoxification and stress tolerance in plants [33], increasing the toxin removal through increased enzyme levels [44]. High contents of gibberellins can ameliorate plant diseases, and gibberellin-related protein expression increased in intercropping E. urophylla $\times$ E. grandis roots (A0A059A3Y5) but was downregulated in D. odorifera (TRINITY_DN35143) at our site. Thus, Eucalyptus can improve the adaptability of the stress response when mixed with an NFT, but the NFT showed inhibition. In addition, thioredoxin is involved in plant stress resistance by regulating stress tolerance, and it was up-regulated in E. urophyllax E. grandis roots (A0A059BPT5). Notably, the number of different stress response proteins in D. odorifera was much lower than that in $E$. urophylla $\times E$. grandis, which indicated that $D$. odorifera was weakly sensitive to environmental stresses. The thaumatin-like protein abundance was increased in the two species, suggesting that it could significantly improve the antifungal activity in the intercropping system. Alcohol dehydrogenase was up-regulated when plants were under stress and was increased in monoculture E. urophylla $\times$ E. grandis (A0A058ZYN2). Importantly, the SOD enzyme, which eliminates the production of harmful substances in metabolism, showed a nonsignificant difference of 1.5 -fold in the roots of the two plants. Nevertheless, the above evidence still showed that Eucalyptus resistance was improved in the intercropping system, and the resistance of $D$. odorifera was hindered. Jasmonic acid (JA) signaling may play an important role in the self-protective responses against opportunistic damage [33]. Our data showed that there was a high level of $\mathrm{JA}$ in the intercropping $D$. odorifera roots, result in increasing the $D$. odorifera stress resistance through rhizosphere interactions.

Overall, the increased levels of stress-responsive proteins in both species indicated that the intercropping systems provided plants with stronger stress resistance than monoculture systems [33-34], i.e., the 
advantages of the interaction of $E$. urophylla $\times$ E. grandis in intercropping systems may improve the ecological adaptation compared to monoculture.

\section{$\mathrm{N}$ metabolism in the molecular structure represents a major consequence $\mathbf{N}$ transfer}

The abundance of $\mathrm{N}$ metabolized proteins changed in the two species via root interactions, with a low protein abundance of GDH and GS in monocropped $E$. urophylla $\times$ E. grandis, but with a high abundance in monocropped $D$. odorifera. GS and GDH are key enzymes in the $\mathrm{N}$ assimilation and metabolism pathways [45], and a previous study showed that GS and GDH in transgenic plants improved plant growth and productivity [33]. Our result as well showed that rhizosphere effects promoted $\mathrm{N}$ assimilation in E. urophylla $\times$ E. grandis roots and productivity but restricted $D$. odorifera. The amino acid metabolic proteins were found at higher levels in monocropped E. urophylla $\times$ E. grandis roots. Peptide-N4-(N-acetylbeta-glucosaminyl) asparagine amidase A (A0A059A9F1) and aspartyl protease AED3 isoform X2 (A0A059AD87) (Table S1) showed higher accumulation in E. urophylla $\times$ E. grandis roots in

monocropping treatment than that in the intercropping treatment, and the two proteins play a leading role in organelle activity, especially during plant senescence and programmed cell death (PCD) [46-47]. Meanwhile, these proteins also participate in abiotic stress responses [48]. Aminotransferase promotes the decomposition of amino acids and the synthesis of new amino acids through the activity of amino acids, which mediates the level of $\mathrm{N}$ metabolism. Our study found higher levels of these proteins in the intercropping system of the two species, i.e., alanine-glyoxylate aminotransferase (A0A059A1E9) and alanine aminotransferase (A0A059AS13) (Table S1) of E. urophylla $\times$ E. grandis and acetylornithine aminotransferase (TRINITY_DN44984) (Table S2), putative branched-chain-amino-acid aminotransferase 7 isoform X1 (TRINITY_DN45090), and tryptophan aminotransferase-related protein 4-like (TRINITY_DN39873) of D. odorifera were up-regulated.

In addition, proteins related to $\mathrm{N}$ compound transport, which promote the synthesis and transport of $\mathrm{N}$ in plants, were only found at a higher abundance in intercropping of $E$. urophylla $\times$ E. grandis but were not found in $D$. odorifera roots. We believe that the higher abundance proteins of $\mathrm{N}$ transport is beneficial to the synthesis and absorption of $\mathrm{N}$ for E. urophylla $\times$ E. grandis. Most importantly, through the analysis of KEGG pathway, the larger proteins of synthesized functional were found than the metabolic proteome in $E$. urophylla $\times E$. grandis, while the opposite result was found in $D$. odorifera, which may be a key signal for the $\mathrm{N}$ transfer from $D$. odorifera to E. urophylla $\times$ E. grandis. These data showed that in addition to increased Eucalyptus $\mathrm{N}$ assimilation through the intercropping system, as well as $\mathrm{N}$ transfer were occurred from the $\mathrm{N}_{2}$-fixing tree to Eucalyptus, as shown in previous studies $[3,15]$.

\section{Proteins involved in protein metabolism cause by $\mathbf{N}$ transfer}

Plants adapt to environmental stress by regulating protein metabolism, such as the synthesis of stressrelated proteins and cold-shock proteins [49]. There were 40 groups of proteins involved in intercropping E. urophylla $\times$ E. grandis roots. We identified 31 (77.5\%) down-regulated and 9 (22.5\%) up-regulated proteins, whereas 9 groups of down-regulated and 41 groups of up-regulated proteins were detected in $D$. 
odorifera roots. Ribosomes, the organelles that catalyze protein synthesis, consist of a small and a large subunit, and these subunits are composed of several RNA species and various structurally distinct proteins, which play a significant role in DNA repair, apoptosis, transcriptional regulation and translational regulation [50]. Many of these proteins showed increased levels in monoculture E. urophylla $\times$ E. grandis roots but decreased levels $D$. odorifera. Moreover, casein kinase 1-like II regulatory subunit is involved in translation, and eukaryotic translation initiation factor isoform $\mathrm{X} 1$ is involved in the initiation phase of eukaryotic translation; both of these proteins were increased in the monoculture E. urophylla $\times$ E. grandis roots but down-regulated in the monoculture $D$. odorifera. In our investigation, we believe that the Eucalyptus and $\mathrm{N}_{2}$-fixing species showed an opposite trend in terms of protein metabolic function, which may also be consistent with our hypothesis that the two species show a decreasing trend. The results are highly consistent with previous results, i.e. the physiological metabolism of Eucalyptus was promoted but restricted the growth of $\mathrm{N}_{2}$-fixing species (see Fig. 1) since $\mathrm{N}$ transfer was from $\mathrm{N}_{2}$-fixing species to Eucalyptus $[3,15]$. Glycine-rich RNA-binding protein (TRINITY_DN41532) was found in intercropping $D$. odorifera with a higher level than in monoculture,which can respond various plant stresses [51]. The 70$\mathrm{kD}$ heat shock (hsp70) proteins are encoded by a highly conserved multigene family whose proteins function in all major subcellular compartments of the cell, and numerous studies have elucidated the hsp70 chaperone functions under stress conditions and in protein metabolism [52]. These proteins were up-regulated in monoculture $E$. urophylla $\times E$. grandis roots, but all of these proteins were down-regulated in D. odorifera roots. Bedon et al. (2011) concluded that the protein abundance expression of Eucalyptus can be down-regulated under stress [53].

\section{$\mathbf{N}$ transfer altered proteins involved in the cell wall and cytoskeleton metabolism of both species}

The cell wall is an important structure that determines cell shape and acts as a critical barrier against pathogens [54]. For example, expansive proteins are a group of cellular structural proteins that relax the noncovalent interaction between components of the plant cell wall and play a defensive role [55]. These proteins were expressed at higher levels in intercropping $E$. urophylla $\times E$. grandis roots than in the monoculture system, but the opposite results were observed in $D$. odorifera. Growing plant cell walls typically extend faster at low $\mathrm{pH}$, and expansive protein activity increases in drought regions [54]. Eucalyptus planting can result in soil acidification [56], as Eucalyptus consumes large quantities of water, thus increasing the abundance of the expansive proteins to promote defense adaptation. The plant cytoskeleton is a highly dynamic network of proteinaceous components consisting mainly of microtubules and microfilaments, which are involved in coordinating cell structure and signaling [57], and these components were up-regulated in D. odorifera roots. Sucrose synthase (SuSy) was found in $D$. odorifera roots (TRINITY_DN40013) and was down-regulated in the intercropping system; this protein is related to cellulose synthesis and increased thickness of cell walls. Gordon et al. (1999) suggested that sucrose metabolism regulates and controls SuSy expression in $\mathrm{N}_{2}$-fixing trees to alter $\mathrm{N}$ fixation efficiency [58]. Some studies have also shown an improvement in the $\mathrm{N}$ fixation efficiency of $\mathrm{N}_{2}$-fixing species 
mixed with Eucalyptus relying on $\mathrm{N}$ transfer $[3,59]$. Therefore, $\mathrm{N}$ transfer may directly alter proteins involved in cell wall and cytoskeletal metabolism at our site.

\section{The glycolytic pathway and the TCA cycle was different of both species}

The glycolytic pathway degrades sugars to pyruvate. The mitochondrial pyruvate carrier was less abundant in the intercropping of both varieties, which decreased the pyruvate carrier protein on the mitochondrial intima. Pyruvate kinase, the rate-limiting enzyme for transferring the high-energy phosphate from phosphoenol pyruvate to ADP and producing ATP, was found in the D. odorifera roots, and it was more abundant in intercropping compared to monocropping, possibly due to the Fe deficiency in intercropped $D$. odorifera. The TCA cycle, the key process of the energy cycle and ultimate metabolic pathway for nutrients, includes three key enzymes for citrate synthase (CS): isocitrate dehydrogenase (ITD) and ketoglutarate dehydrogenase alpha (KLDA). CS (A0A059AKY9, A0A059B6K2, A0A059BEH3, A0A059D8E5) was only found in the $E$. urophylla $\times E$. grandis roots. ATP-citrate synthase alpha chain protein 3 (ACLA-3) (A0A059BEH3) abundance was down-regulated in the intercropping system. ACLA-1 (A0A059D8E5) was increased in the intercropping treatment, which reduced the synthetic accumulation of chlorophyll and carotene in plants to retard plant dwarfing and senescence. It is largely due to the increase $\mathrm{N}$ content by $\mathrm{N}$ transfer from aodorifera to $E$. urophylla $\times$ E. grandis. NADP-dependent malic enzymes catalyze the oxidation decarboxylation of malic acid pyruvate, participate in the glycolytic pathway and TCA cycle, and play a defensive role in plants [60]. Our study found the NADP-dependent malic enzyme isoform X1 (A0A059BVK1) in the E. urophylla $\times$ E. grandis roots and was higher in intercropping than that in monoculture. Nevertheless, aconitate hydratase is the key enzyme responsible for the conversion of citrate into isocitrate in the TCA cycle, and enolase is the enzyme responsible for catalyzing the reversible dehydration of 2-phospho-D-glycerate into phosphoenolpyruvate as part of the glycolytic and gluconeogenesis pathways [33], but there were no significant difference in these two enzymes of both varieties between the intercropping and monocropping treatments.

\section{Conclusion}

The results encourage us to recommend $E$. urophylla $\times E$. grandis/D. aodorifera plantations. $N$ transfer occurred from $D$. aodorifera to $E$. urophylla $\times E$. grandis and established a virtuous cycle between nutrient provision and $E$. urophylla $\times E$. grandis growth to provide higher yields. Rhizosphere effects promoted $\mathrm{N}$ assimilation and $\mathrm{N}$ transfer through enhancing the levels of some protein species, such as ATP synthase, $\mathrm{GS}$ and GDH. Meanwhile, it can also increase the stress tolerance of E. urophylla $\times$ E. grandis, i.e. the advantages of this intercropping system may improve the ecological adaptation of plants to environmental stress. $\mathrm{N}$ uptake was not changed by the rhizosphere effects in $D$. odorifera, perhaps because of its own $\mathrm{N}$ fixation. Notably, E. urophylla $\times$ E. grandis was the beneficiary in the process of $\mathrm{N}$ transfer, there were more different proteins involved in the synthesis pathway than that of the metabolic pathway, but the opposite result for $D$. odorifera; The two groups of $\mathrm{N}$ compound transporter were found in $E$. urophylla $\times$ E. grandis, i.e. the molecular mechanism of the $\mathrm{N}$ transfer from $D$. odorifera to $E$. 
urophylla $\times$ E. grandis was explained by proteomics at our site. However, studies on the possible benefits of $\mathrm{N}$ transfer in this system should be provided to evaluate the long-term influence on productivity. Therefore, more trials focused in these environmental conditions, analytical methods and field experimentation assessments are needed to verify these findings and recommendations.

\section{Methods}

\section{Experimental site and design}

The experiments were carried out in the greenhouse at Guangxi University, Guangxi, China $\left(108^{\circ} 17^{\prime} 30.3^{\prime \prime} \mathrm{E}, 22^{\circ} 51^{\prime} 4.79^{\prime \prime} \mathrm{N}\right)$ on the May 18 th, 2017 , with air temperatures ranging from $21^{\circ} \mathrm{C}$ to $28^{\circ} \mathrm{C}$. The soil, previously planted with Pinus massoniana was collected at Liang Fengjiang Experimental Station, Nanning, China. The following characteristics were $1.22 \mathrm{~g}$ total $\mathrm{N} \mathrm{kg}^{-1}, 0.57 \mathrm{~g}$ total $\mathrm{P} \mathrm{kg}^{-1}$, $11.85 \mathrm{~g} \mathrm{~K} \mathrm{~kg}^{-1}$, and $\mathrm{pH} 4.65$.

\section{Experiment 1}

One D. odorifera plant was intercropped with one E. urophylla $\times E$. grandis plant in each pot $(50 \mathrm{~cm}$ diameter and $45 \mathrm{~cm}$ depth). All the plant materials are very common in south China and the same as Yao et al. [3], which were obtained from the commercial nursery of Ba Gui, Naning. To avoid the nutrient lost, and plastic leakproof trays were placed at the bottom of the pot. Plants were watered to keep the soil moisture at $40-80 \%$ of the water holding capacity during the entire growth stage. All treatments were in a complete random design with three replicates for each treatment. After six months, one gram of the root tips of E. urophylla $\times$ E. grandis and D. odorifera was taken in December 2017, and each root was washed with deionized water and stored in liquid $\mathrm{N}$ (at $-80^{\circ} \mathrm{C}$ ) for 10 minutes for further analyses. At harvest, plants from the intercropping were separated into $E$. urophylla $\times E$. grandis and $D$. odorifera. The roots of the two species were separated by hand and washed carefully to remove soil. Root length and surface area were scanned by an Epson root scanner and were used to obtain image analysis by WinRHIZON Pro. Then, the harvested material was dried at $60{ }^{\circ} \mathrm{C}$ until a constant dry weight was obtained. The dried root material was ground in a ball mill and passed through a $0.2-\mathrm{mm}$ screen, and the total $\mathrm{N}$ content was determined by a continuous flow chemical analyzer (AA3).

\section{Experiment $2\left({ }^{15} \mathrm{~N}\right.$ labeling)}

In this experiment, the plant growth conditions, ${ }^{15} \mathrm{~N}$ labeling and isotopic analyses were the same as those used by Yao et al. [3]. The value of plant ${ }^{15} \mathrm{~N}$ atom \% excess was calculated by the following equation [61-62].

The ${ }^{15} \mathrm{~N}$ content of receiver and donor leaf, stem and root were calculated

$$
\text { Excess }{ }^{15} \text { Ncontent }{ }_{\text {compartment }}=\frac{\text { Aom } \%{ }^{15} \mathrm{~N} \text { excess } \times \text { Total } \quad \mathrm{N}}{100}
$$


The total excess ${ }^{15} \mathrm{~N}$ content of the whole plant was calculated by summing the excess ${ }^{15} \mathrm{~N}$ content in roots, stems and leaves.

The proportion of the total $\mathrm{N}$ in the receiver derived from the donor was calculated using the following equation

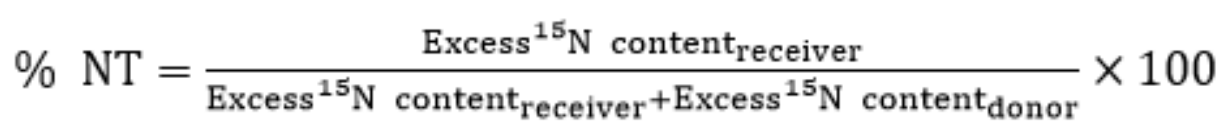

where $\% \mathrm{NT}$ is the percentage of total $\mathrm{N}$ transferred from donor to receiver.

The amount of $\mathrm{N}\left(\mathrm{mg} \mathrm{plant}^{-1}\right)$ transferred from the donor was calculated as follows:

$$
\mathrm{N}_{\text {transfer }}=\frac{\% \mathrm{NT} \times \text { total } \mathrm{N}_{\text {donor }}}{100}
$$

where $\mathrm{N}_{\text {transfer }}$ is the unidirectional net transfer from D. odorifera to E. urophylla $\times E$. grandis.

\section{Protein extraction and preparation}

The samples were taken from a $-80^{\circ} \mathrm{C}$ freezer, the appropriate amount of tissue sample was added to a liquid $\mathrm{N}$-precooled mortar, and the liquid $\mathrm{N}$ sample was ground fully to powdered. Soluble protein was extracted by adding four volumes of lysis buffer (10 mM dithiothreitol (DTT), 1\% Protease Inhibitor Cocktail and $2 \mathrm{mM}$ EDTA) to $400 \mathrm{mg}$ lyophilized leaf powder followed by vortexing at $4{ }^{\circ} \mathrm{C}$ and centrifugation at $5,500 \mathrm{~g}$ for $10 \mathrm{~min}$. Finally, the supernatant was collected and added to $0.1 \mathrm{M}$ ammonium acetate/methanol in a 5-fold volume to precipitate overnight. The remaining precipitate was washed with cold acetone three times, the protein was redissolved in $8 \mathrm{M}$ urea, and the protein concentration was determined with a BCA kit [63].

\section{TMT/ITRAQ Labeling}

For digestion, the protein solution was reduced with $5 \mathrm{mM}$ dithiothreitol for $30 \mathrm{~min}$ at $56^{\circ} \mathrm{C}$ and alkylated with $11 \mathrm{mM}$ iodoacetamide for $15 \mathrm{~min}$ at room temperature in the dark. The protein sample was then diluted by adding $100 \mathrm{mM}$ TEAB to urea at a concentration of less than $2 \mathrm{M}$. Finally, trypsin was added at a 1:50 trypsin-to-protein mass ratio for the first digestion overnight and a 1:100 trypsin-to-protein mass ratio for a second $4 \mathrm{~h}$ digestion. The peptides were desalted and vacuum-dried after trypsin digestion. Then, the sample was reconstituted in 0.5 M TEAB and processed with the TMT kit/iTRAQ kit [64].

\section{Bioinformatic Analysis}

Gene Ontology (GO) is a major bioinformatics initiative to unify the representation of gene and gene product attributes across all species, which were created by searching the UniProt-GOA database (http://www.ebi.ac.uk/GOA/) [65]. The functional descriptions of the identified proteins were annotated by InterProScan (a sequence analysis application) (http://www.ebi.ac.uk/interpro/) based on the protein 
sequence alignment method, and the InterPro domain database was used. Central to the database are diagnostic models, known as signatures, against which protein sequences can be searched to determine their potential function.

The Kyoto Encyclopedia of Genes and Genomes (KEGG) connects known information on molecular interaction networks, such as pathways and complexes (the "Pathway" database), information about genes and proteins generated by genome projects (including the gene database) and information about biochemical compounds and reactions (including compound and reaction databases). We used the KEGG online service tool KAAS to annotate the protein KEGG database descriptions. Then, we mapped the annotation results on the KEGG pathway database using the KEGG online service tool KEGG mapper.

Proteins were classified by GO annotation into three categories: biological process, cellular compartment and molecular function. For each category, a two-tailed Fisher's exact test was employed to test the enrichment of the differentially expressed protein against all identified proteins. GO categories with a corrected $p$-value $<0.05$ were considered significant [65].

KEGG database was used to identify enriched pathways by a two-tailed Fisher's exact test to test the enrichment of the differentially expressed protein against all identified proteins. Pathways with a corrected $p$-value $<0.05$ were considered significant. These pathways were classified into hierarchical categories according to the KEGG website [65].

For each category of proteins, the InterPro (a resource that provides functional analysis of protein sequences by classifying them into families and predicting the presence of domains and important sites) database was used, and a two-tailed Fisher's exact test was employed to test the enrichment of the differentially expressed protein against all identified proteins. Protein domains with a p-value $<0.05$ were considered significant.

\section{PRM analysis}

For digestion, the protein solution was reduced with $5 \mathrm{mM}$ dithiothreitol for $30 \mathrm{~min}$ at $56^{\circ} \mathrm{C}$ and alkylated with $11 \mathrm{mM}$ iodoacetamide for $15 \mathrm{~min}$ at room temperature in darkness. The protein sample was then diluted to obtain urea concentrations less than 2M. Trypsin was added at a 1:50 trypsin-to-protein mass ratio for the first digestion overnight and a 1:100 trypsin-to-protein mass ratio for a second 4 h-digestion.

The tryptic peptides were dissolved in $0.1 \%$ formic acid (solvent A) and directly loaded onto a homemade reverse-phase analytical column, all at a constant flow rate of $500 \mathrm{~nL} / \mathrm{min}$ on an EASY-nLC 1000 UPLC system. The peptides were subjected to an NSI source followed by tandem mass spectrometry (MS/MS) in a Q Exactive ${ }^{\mathrm{TM}}$ Plus system (Thermo) coupled online to UPLC. The resulting MS data were processed using Skyline (v.3.6). Peptide settings: enzyme was set as Trypsin [KR/P], Max missed cleavage set as 2. The peptide length was set as 7-25.

\section{Statistical analysis}


MS Excel and SPSS software were used for the data analyses. The statistical significance of differences between treatments was determined by analysis of variance (ANOVA) and the LSD (least significant difference) multiple comparisons. The figures were created from the "gplots" R-package and SigmaPlot 13.0.

\section{Abbreviations}

EDTA: Ethylenediamine Tetraacetic Acid; BCA: Bicinchoninic Acid; RSD: Relative Standard Deviation; TMT; Tandem Mass Tag; SOD: Superoxide Dismutase; PMR: Parallel Reaction Monitoring; LC-MS/MS: Liquid Chromatography-tandem mass spectrometry; iTRAQ: Isobaric Tags for Relative and Absolute Quantitation. ADP: Adenosine-diphosphate; ATP: Adenosine-triphosphate; TCA: Tricarboxylic Acid

\section{Declarations}

\section{Acknowledgements}

The authors gratefully acknowledge American Journal Experts (www.aje.cn) and Yahui Lan for their linguistic assistance during the preparation of this manuscript.

\section{Authors' contributions}

SMY, $X Y$ and MY designed the experiments; $X Y Y, L L, G F$ and $Y Z H$ carried out the experiments; $X Y Y, L N L$ and SMY analyzed the experimental results, the data and developed analysis tools; XYY, SMY and MY wrote the manuscript, and all authors read and approved the final manuscript.

\section{Competing interests}

No author has any competing interest.

\section{Availability of data and materials}

The data generated or analyzed in this study are included in this article and its supplementary information files. Other materials that support the findings of this study are available from the corresponding author on reasonable request.

\section{Ethics approval and consent to participate}

Not applicable. 


\section{Consent for publication}

Not applicable.

\section{Funding}

This work was supported by the National Natural Science Foundation of China (No. 31460196) to Shaoming YE and the Innovation Project of Guangxi Graduate Education (YCBZ2018012) to Xianyu Yao. The funding agencies were not involved in the designing of the study and collection, analysis and interpretation of the data, and in the writing of the manuscript.

\section{Declarations}

Not applicable

\section{References}

1. Epron D, Nouvellon Y, Mareschal L, Moreira RM, Koutika L-S, Geneste B, Delgado-Rojas JS, Laclau J-P, Sola G, Gonçalves JLM, Bouillet J-P. Partitioning of net primary production in Eucalyptus and Acacia stands and in mixed-species plantations: Two case-studies in contrasting tropical environments. Forest Ecol Manag. 2013; 301: 101-111. doi.org/10.1016/j.foreco.2012.10.034.

2. Chen L, Fu S. Enhanced cellulase hydrolysis of Eucalyptus waste fibers from pulp mill by tween80assisted ferric chloride pretreatment. J Agric Food Chem. 2013; 61: 3293-3300.

3. Yao XY, Li YF, Liao LN, Sun G, Wang HX, Ye SM Enhancement of nutrient absorption and interspecific nitrogen transfer in a Eucalyptus urophyllax eucalyptus grandis and Dalbergia odoriferamixed plantation. Forest Ecol Manag. 2019; 449:117465. https://doi.org/10.1016/j.foreco.2019.117465

4. Laclau J-P, Ranger J, Gonçalves JLM, Maquère V, Krusche AV, M’Bou AT, Nouvellon Y, Saint-André L, Bouillet J-P, Piccolo MC, Deleporte P. Biogeochemical cycles of nutrients in tropical Eucalyptus plantations: main features shown by intensive monitoring in Congo and Brazil. Forest Ecol Manag. 2010; 259: 1771-1785.

5. Smethurst P, Holz G, Moroni M, Baillie C. Nitrogen management in Eucalyptus nitens plantations. For Ecol Manag. 2004; 193: 63-80.

6. Binkley D, Burnham H, Allen HL. Water quality impacts of forest fertilization with nitrogen and phosphorus. Forest Ecol Manag. 1999; 121: 191-213.

7. Laclau JP, Ranger J, Deleporte P, Nouvellon Y, Saint-André L, Marlet S, Bouillet J-P. Nutrient cycling in a clonal stand of Eucalyptus and an adjacent savanna ecosystem in Congo. 3. Input-output budgets and consequences for the sustainability of the plantations. Forest Ecol Manage. 2005; 210: $375-391$. 
8. Binkley D, Senock R, Bird S, Cole TG. Twenty years of stand development in pure and mixed stands of Eucalyptus saligna and nitrogen-fixing Falcataria moluccana. Forest Ecol Manag. 2003; 182: 93102.

9. Voigtlaender M, Laclau JP, Piccolo MDC, Moreira MZ, Nouvellon Y, Ranger J. Introducing Acacia mangium trees in Eucalyptus grandis plantations: consequences for soil organic matter stocks and N mineralization. Plant Soil. 2012; 352: 99-111. doi:10.1007/s11104-011-0982-9.

10. Malezieux E. Designing cropping systems from nature. Agron Sustain Dev. 2012, 32: 15-29.

11. Pagano M C , Scotti MR, Cabello MN. Effect of the inoculation and distribution of mycorrhizae in plathymenia reticulata benth under monoculture and mixed plantation in Brazil. New Forest. 2009; 38(2):197-214.

12. Tchichelle SV, Mareschal L, Koutika L-S, Epron D. Biomass production, nitrogen accumulation and symbiotic nitrogen fixation in a mixed species plantation of eucalypt and acacia on a nutrient-poor tropical soil. Forest Ecol Manag. 2017; 403: 103-111. doi.org/10.1016/j.foreco.2017.07.041.

13. Bristow M, Vanclay JK, Brooks L, Hunt M. Growth and species interactions of Eucalyptus pellita in a mixed and monoculture plantation in the humid tropics of north Queensland. Forest Ecol Manag. 2006; 233: 285-294.

14. Forrester DI, Bauhus J, Cowie AL, Vanclay JK. Mixed-species plantations of Eucalyptus with nitrogenfixing trees: a review. Forest Ecol Manag. 2006; 233: 211-230. doi:10.1016/j.foreco.2006.05.012.

15. Paula RR, Bouillet J-P, Trivelin PCO, Zeller B, Gonçalves JLM, Nouvellon Y, Bouvet J-M, Plassard C, Laclau J-P. Evidence of short-term belowground transfer of nitrogen from Acacia mangium to Eucalyptus grandis trees in a tropical planted forest. Soil Biol Biochem. 2015; 91: 99-108. doi.org/10.1016/j.soilbio.2015.08.017.

16. Tchichelle SV, Epron D, Mialoundama F, Koutika LS, Harmand JM, Bouillet J-P, Mareschal L Differences in nitrogen cycling and soil mineralisation between a eucalypt plantation and a mixed eucalypt and Acacia mangium plantation on a sandy tropical soil. South Forests. 2017; 79: 1-8. doi.org/10.2989/20702620.2016.1221702.

17. Forrester DI, Schortemeyer M, Stock WD, Jürgen B, Cowie AL. Assessing nitrogen fixation in mixedand single-species plantations of Eucalyptus globulus and Acacia mearnsii. Tree Physiol. 2007; 27: 1319-1328.

18. He Y, Cornelissen JHC, Wang P, Dong M, Ou J. Nitrogen transfer from one plant to another depends on plant biomass production between conspecific and heterospecific species via a common arbuscular mycorrhizal network. Environ Sci Pollut Res. 2019; 26: 88288837. https://doi.org/10.1007/s11356-019-04385-x

19. Paula RR, Bouillet JP, Goncalves de M, José L, Trivelin PCO, Fabiano DCB, Nouvellon Y, Oliveira JC, Júnior JC, Bordron B, Laclau J-P. Nitrogen fixation rate of Acacia mangium wild at mid rotation in Brazil is higher in mixed plantations with Eucalyptus grandis Hill ex Maiden than in monocultures. Ann Forest Sci. 2018; 75: 1-14. doi.org/10.1007/s13595-018-0695-9. 
20. Parrotta JA, Baker DD, Fried M. Changes in dinitrogen fixation in maturing stands of Casuarina equisetifolia and Leucaena leucocephala. Can J For Res. 1996; 19: 24-34.

21. Siddique I, Engel VL, Parrota JA, Lamb D, Nardoto GB, Ometto JPHB, Martinelli LA, Schimdt S. Dominance of legume trees alters nutrient relations in mixed species forest restoration plantings within seven years. Biogeochemistry. 2008; 88: 89-101.

22. Takehisa H, Sato Y, Igarashi M, TAbiko T, Antonio B A, Kamatsuki K, Minami H, Namiki N, Inukai Y, Nakazono M, Nagamura Y. Genome-wide transcriptome dissection of the rice root system: implications for developmental and physiological functions. Plant J. 2015; 69: 126-140.

23. Dayakar S, Komandur S, Sadhnani MD, Kumar VB, Sreedhar P, Naik S, Rao S, Rath PC, Raju NR, Agarwal KM, Sesikeran BS. Role of coagulation factors in coronary thrombosis in young individualsa hospital based study. Atherosclerosis. 2009; 207: 1-13. doi:10.1016/j.atherosclerosis.2009.09.063

24. Wang R, Wang Q, Zhao N, Xu Z, Zhu X, Jiao C. Different phylogenetic and environmental controls of first-order root morphological and nutrient traits: evidence of multidimensional root traits. Funct Ecol. 2018; 32: 29-39. doi:10.1111/1365-2435.12983.

25. Champoux MC, Wang G, Sarkarung SDJ, Mackill JC, O'Toole JC, Huang N. Locating genes associated with root morphology and drought avoidance in rice via linkage to molecular markers. Theor Appl Genet. 1995; 90: 969-981.

26. Yadav R, Courtois B, Huang N, Mclaren G. Mapping genes controlling root morphology and root distribution in a double-haploid population of rice. Theor Appl Genet. 1997; 94: 619-632.

27. Muccilli V, Licciardello C, Fontanini D, Cunsolo V, Capocchi A, Saletti R. Root protein profiles of two citrus rootstocks grown under iron sufficiency/deficienc conditions. EurJ Mass Spectrom. 2013; 19 : 305-324.

28. Bahrman N, Gouy A, Deviennebarret F, Hirel B, Vedele F, Le GJ. Differential change in root protein patterns of two wheat varieties under high and low nitrogen nutrition levels. Plant Sci. 2005; 168: 8187.

29. Burgess $P$, Huang $B$. Root protein metabolism in association with improved root growth and drought tolerance by elevated carbon dioxide in creeping bentgrass. Field Crop Res. 2014; 165: 80-91.

30. Kiegle E, Moore CA, Haseloff J, Tester MA, Knight MR. Cell-type- specific calcium responses to drought, salt and cold in the arabidopsis root. Plant J. 2000; 23: 267-278.

31. Diz AP, MartíNez-FernÁNdez M, RolÁN-Alvarez E. Proteomics in evolutionary ecology: linking the genotype with the phenotype. Mol Ecol. 2012; 21: 1060-1080.

32. Cravatt BF, Simon GM, Yates JR. The biological impact of mass-spectrometry-based proteomics. Nature. 2007; 450: 991-1000.

33. Xiong H, Shen H, Zhang L, Zhang Y, Guo X, Wang P. Comparative proteomic analysis for assessment of the ecological significance of maize and peanut intercropping. J Proteomics. 2013; 78: 447460.

34. Yan S, Du X, Wu F, Li L, Li C, Meng Z. Proteomics insights into the basis of interspecific facilitation for maize (Zea mays) in faba bean (Vicia faba)/maize intercropping. J Proteomics. 2014; 109: 111- 
124.doi.org/10.1016/j.jprot.2014.06.027.

35. Vasilakoglou I, Dhima K, Lithourgidis A, Eleftherohorinos I. Competitive ability of winter cerealcommon vetch intercrops against sterile oat. Exp Agric. 2008; 44: 509-520. doi:10.1017/s0014479708006728.

36. Lynch JP. Root phenes that reduce the metabolic costs of soil exploration: opportunities for $21 \mathrm{st}$ century agriculture. Plant Cell Environ. 2015; 38: 1775-1784.

37. Bini D, Santo, CAD, Bouillet JP, Goncalves JLM, Cardoso EJBN. Eucalyptus grandis, and Acacia mangium, in monoculture and intercropped plantations: evolution of soil and litter microbial and chemical attributes during early stages of plant development. Applied Soil Ecol. 2013; 63: 57-66. doi:10.1016/j.apsoil.2012.09.012.

38. Acevedo M, Rubilar R, Dumroese RK, Ovalle JF, Sandova S, Chassin-Trubert R. Nitrogen loading of Eucalyptus globulus seedlings: nutritional dynamics and influence on morphology and root growth potential. New Forest. 2020. https://doi.org/10.1007/s11056-020-09778-2

39. Shi H, Ye T, Zhong B, Liu X, Chan Z. Comparative proteomic and metabolomics analyses reveal mechanisms of improved cold stress tolerance in bermudagrass (Cynodon dactylon (L). Pers.) by exogenous calcium. J IntegrPlant Biol. 2014; 56: 1064-1079.

40. Boudreau MA, Shew BB, Andrako LED. Impact of intercropping on epidemics of groundnut leaf spots: defining constraints and opportunities through a 7-year field study. Plant Pathol. 2016; 65: 601-611.

41. Huang X, Liu S, You Y, Wen Y, Wang H, Wang J. Microbialcommunity and associated enzymes activity influence soil carbon chemical composition in Eucalyptus urophylla plantation with mixing $\mathrm{N}_{2}$-fixing species in subtropical China. Plant Soil. 2017; 414: 199-212. doi:10.1007/s11104-016-3117-5.

42. Fu X, Harberd NP. Auxin promotes Arabidopsis root growth by modulating gibberellin response. Nature. 2003; 421: 740-743.

43. Ishikawa T, Shigeoka S. Recent advances in ascorbate biosynthesis and the physiological significance of ascorbate peroxidase in photosynthesizing organisms. Biosci Biotechnol Biochem. 2008; 72: 1143-1154.

44. Jain M, Ghanashyam C, Bhattacharjee A. Comprehensive expression analysis suggests overlapping and specific roles of rice glutathione S-transferase genes during development and stress responses. BMC Genomics. 2010; 11: 73. http://www.biomedcentral.com/1471-2164/11/73

45. Miflin BJ, Habash DZ. The role of glutamine synthetase and glutamate dehydrogenase in nitrogen assimilation and possibilities for improvement in the nitrogen utilization of crops. J Exp Bot. 2002; 53: 979-87.

46. Bhalerao R, Keskitalo J, Sterky F. Gene expression in autumn leaves. Plant Physiol. 2003; 131, 43042.

47. Bryksa BC, Bhaumik P, Magracheva E, De Moura DC, Kurylowicz M, Zadanov A, Dutcher JR, Wlodawer A, Yada R. Structure and mechanism of the saposin-like domain of a plant aspartic protease. Journal of Biol Chem. 2011; 286: 28265-28275. 
48. Guevara MG, Oliva CR, Huarte M. An aspartic protease with antimicrobial activity is induced after infection and wounding in intercellular fluids of potato tubers. Eur J Plant Pathol. 2002; 108: 131137.

49. Ruelland E, Vaultier M N, Zachowski A, Hurry V. Chapter 2 cold signalling and cold acclimation in plants. Adv Bot Res. 2009; 49: 35-150. doi.org/10.1016/S0065-2296(08)00602-2

50. Mazumder B, Sampath P, Seshadri V, Maitra RK, Dicorleto PE, Fox PL. Regulated release of I13a from the 60 s ribosomal subunit as a mechanism of transcript-specific translational control. Cell. 2003; 115: 190-198.

51. Lorkovic ZJ. Role of plant RNA-binding proteins in development, stress response and genome organization. Trends Plant Sci. 2009; 14: 230-236.

52. Sung DY, Vierling E, Guy CL. Comprehensive expression profile analysis of the arabidopsis hsp70 gene family. Plant Physiol. 2001; 126: 789-800.

53. Bedon F, Majada J, Feito I, Chaumeil P, Dupuy JW, Lomenech A-M, Barre A, Gion J-M, Plomion C. Interaction between environmental factors affects the accumulation of root proteins in hydroponically grown Eucalyptus globulus (labill.). Plant Physiol Bioch. 2011; 49: 69-76. doi:10.1016/j.plaphy.2010.09.020

54. Cosgrove DJ. Loosening of plant cell walls by expansins. Nature. 2000; 407: 321-326.

55. Stare BC, Lamovšek J, Sirca S, Urek G. Assessment of sequence variability in putative parasitism factor, expansin (expB2) from diverse populations of potato cyst nematode Globodera rostochiensis. Physiol Mol Plant P. 2012; 79: 49-54. doi:10.1016/j.pmpp.2012.04.002.

56. Rhoades C, Binkley D. Factors influencing decline in soil pH in Hawaiian Eucalyptus and Albizia plantations. Forest Ecol Manag. 1996; 80: 47-56.

57. Jiang HX, Yang LT, Qi YP, Lu YB, Chen LS. Root iTRAQ protein profile analysis of two Citrus species differing in aluminum-tolerance in response to long-term aluminum-toxicity. BMC Genomics. 2015, 16: 949. doi 10.1186/s12864-015-2133-9.

58. Gordon AJ, Minchin FR, James CL. Sucrose synthase in legume nodules is essential for nitrogen fixation. Plant Physiol. 1999; 120: 867-877.

59. Bouillet JP, Laclau JP, Goncalves JLM, Moreira MZ, Trivelin P, Jourdan C, Galiana A. Mixed-species plantations of Acacia mangium and Eucalyptus grandis in Brazil 2. Nitrogen accumulation in the stands and $\mathrm{N}_{2}$ biological fixation. Forest Ecol Manag. 2008; 255: 3918-4393. doi:10.1016/j.foreco.2007.10.049.

60. Artus NN, Edwards GE. NAD-malic enzyme from plants. FEBS Lett. 1985; 182: 225-33.

61. Chalk PM, Peoples MB, McNeill AM, Boddey RM, Unkovich MJ, Gardener MJ, Silva CF, Chen D. Methodologies for estimating nitrogen transfer between legumes and companion species in agroecosystems: A review of ${ }^{15} \mathrm{~N}$-enriched techniques. Soil Biol Biochem. 2014; 73:1021. http://dx.doi.org/10.1016/j.soilbio.2014.02.005 
62. Fernandez M, Malagoli P, Vernay A, Thierry Améglio, Balandier, P. Below-ground nitrogen transfer from oak seedlings facilitates Molinia growth: ${ }^{15} \mathrm{~N}$ pulse-chase labelling. Plant Soil. 2020. https://doi.org/10.1007/s11104-020-04473-9

63. Neilson K A, Mariani M, Haynes P A. Quantitative proteomic analysis of cold-responsive proteins in rice. Proteomics. 2011; 11: 1696-1706.

64. Xu X, Liu T, Yang J, Chen L, Liu B, Wang L. The first whole-cell proteome and lysine-acetylome-based comparison between trichophyton rubrum conidial and mycelial stages. J Proteome Res acs. jproteome. 2018. 7b00793. doi: 10.1021/acs.jproteome.7b00793.

65. Peng JX, He PP, Wei PY, Zhang B, Zhao YZ, Li QY, Chen XL, Peng M, Zeng DG, Yang CL, Chen X. Proteomic Responses Under Cold Stress Reveal Unique Cold Tolerance Mechanisms in the Pacific White Shrimp (Litopenaeus vannamei). Front Physiol. 2018; 9: 1399. doi:10.3389/fphys.2018.01399.

\section{Figures}



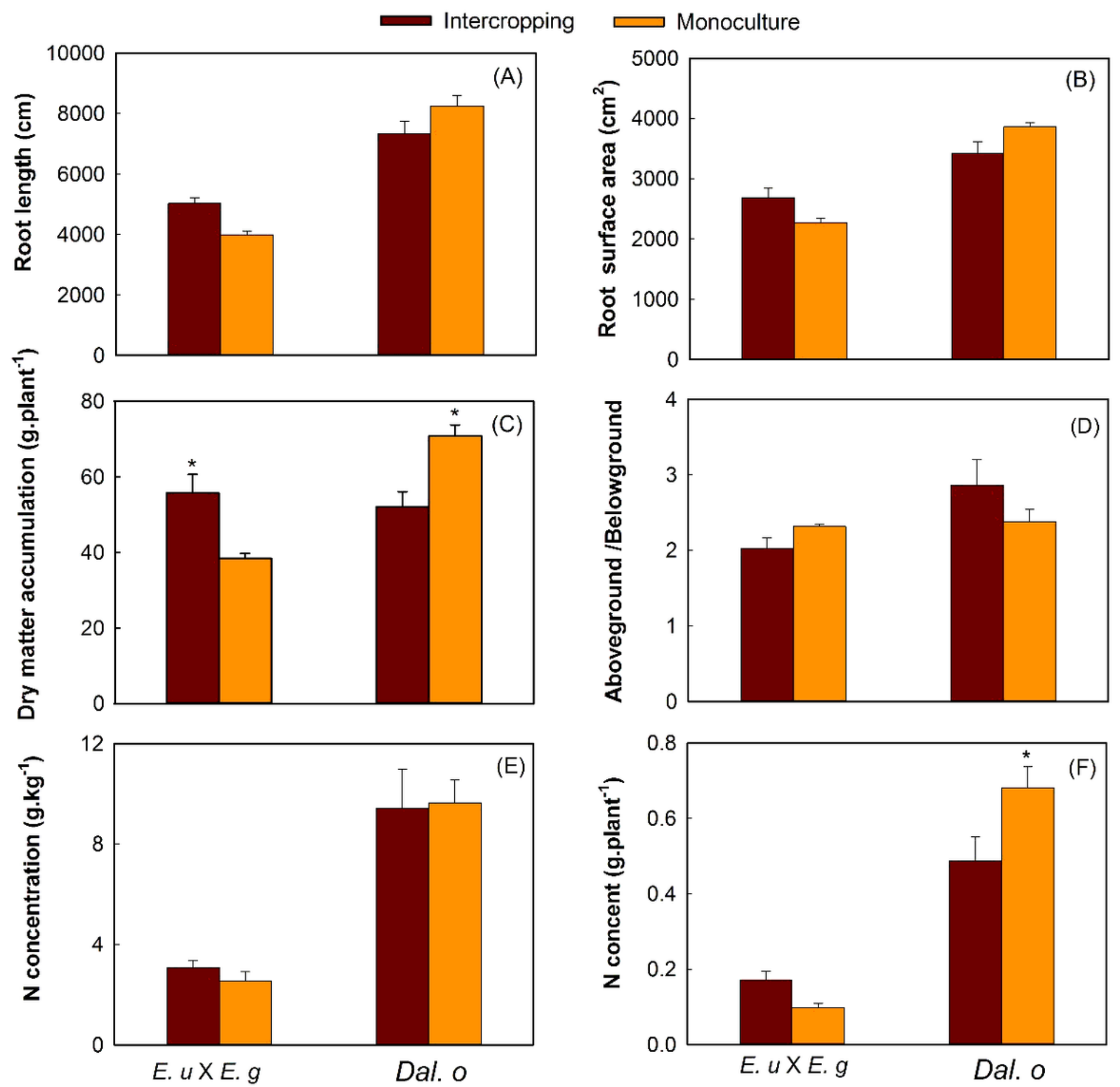

Figure 1

Total root length $(A)$ of E. urophylla $\times$ E. grandis and D. odorifera under different planting systems. Total surface area (B); Biomass (C); Biomass ratio of aboveground and underground parts (D); Root nitrogen concentration $(\mathrm{E})$; Root nitrogen content $(\mathrm{F})$ Note: E. $u \times \mathrm{E}$. $\mathrm{g}$ is E. urophylla $\times$ E. grandis and D. odorifera Dal. o and D. odorifera. 


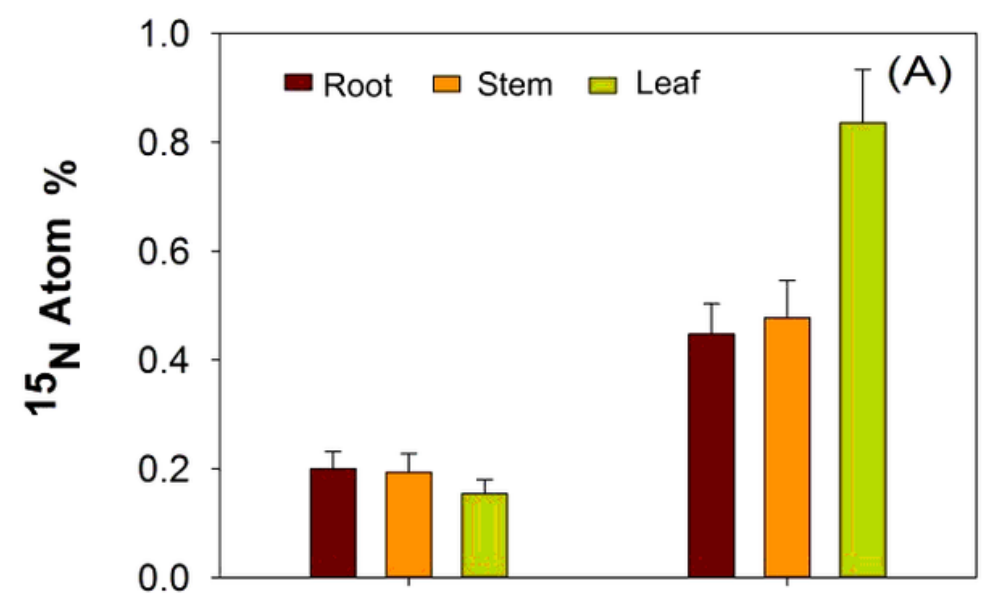

E. urophylla $\times$ E. grandis $D$. odorifera

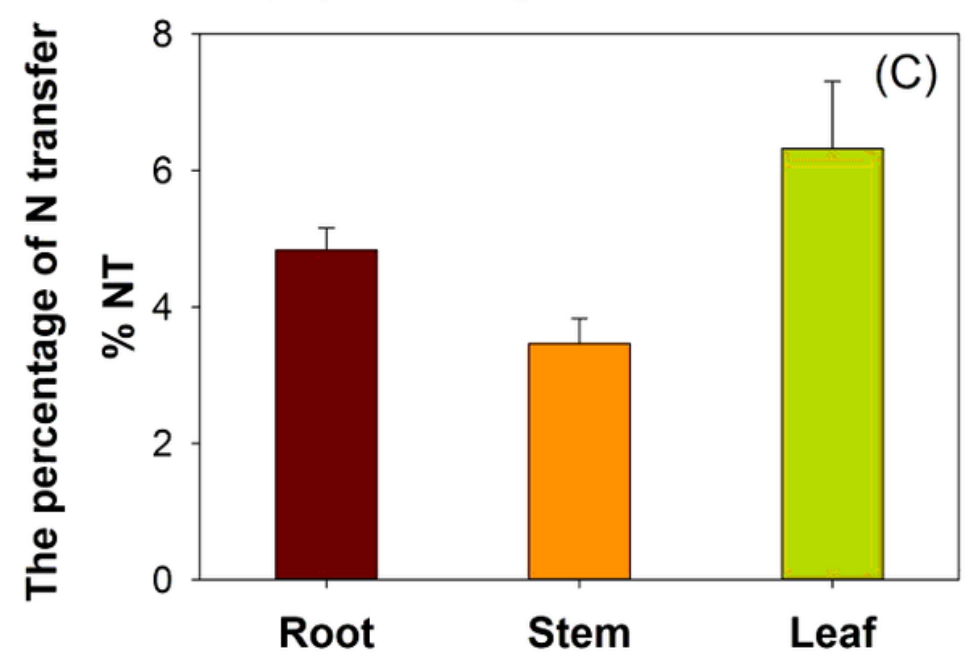

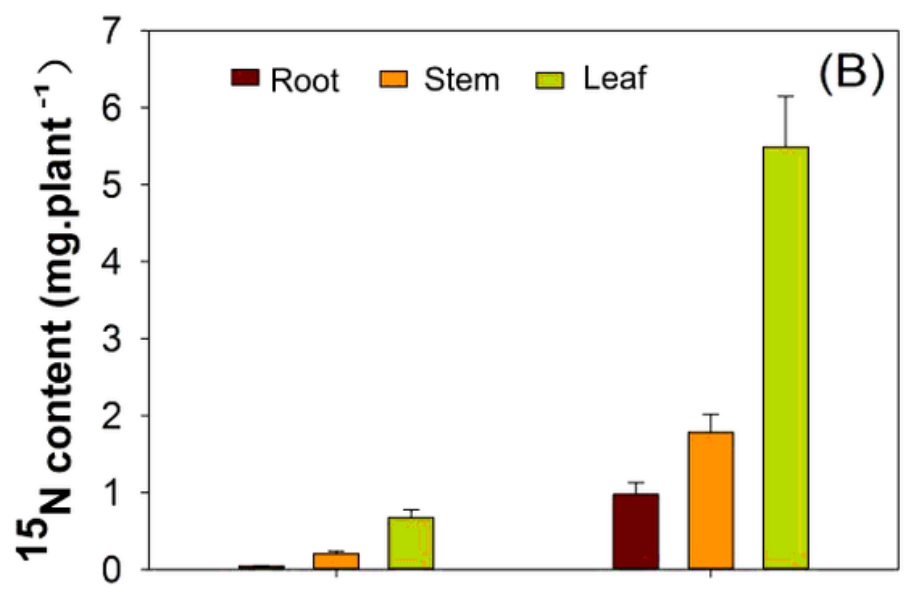

E. urophylla $\times$ E. grandis $D$. odorifera

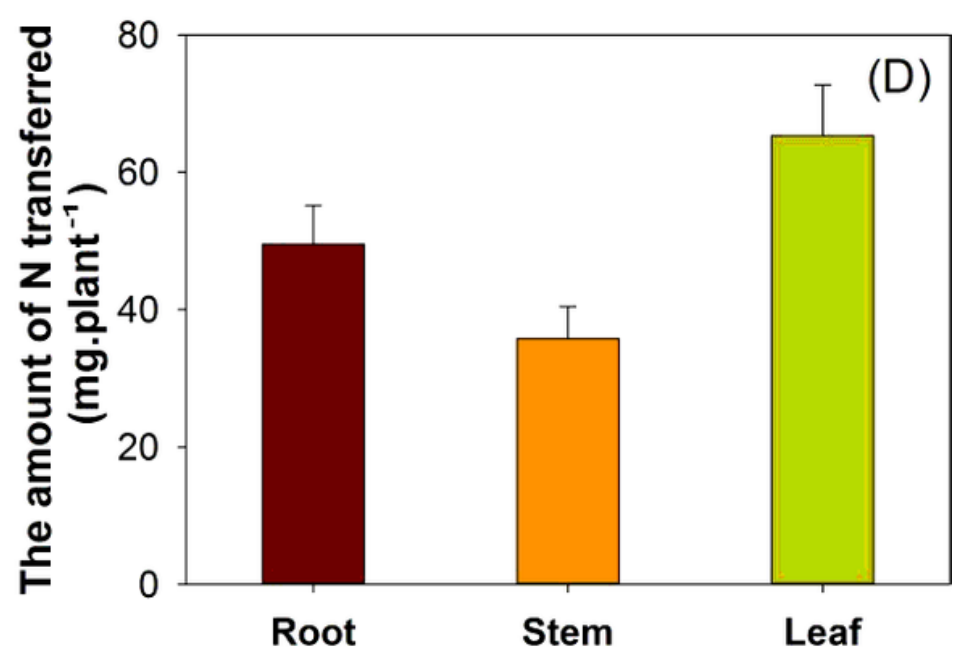

Figure 2

Atom $\% 15 \mathrm{~N}$ in plant components and $\mathrm{N}$ transfer between $\mathrm{D}$. odorifera and $\mathrm{E}$. urophylla $\times \mathrm{E}$. grandis in an intercropping system 

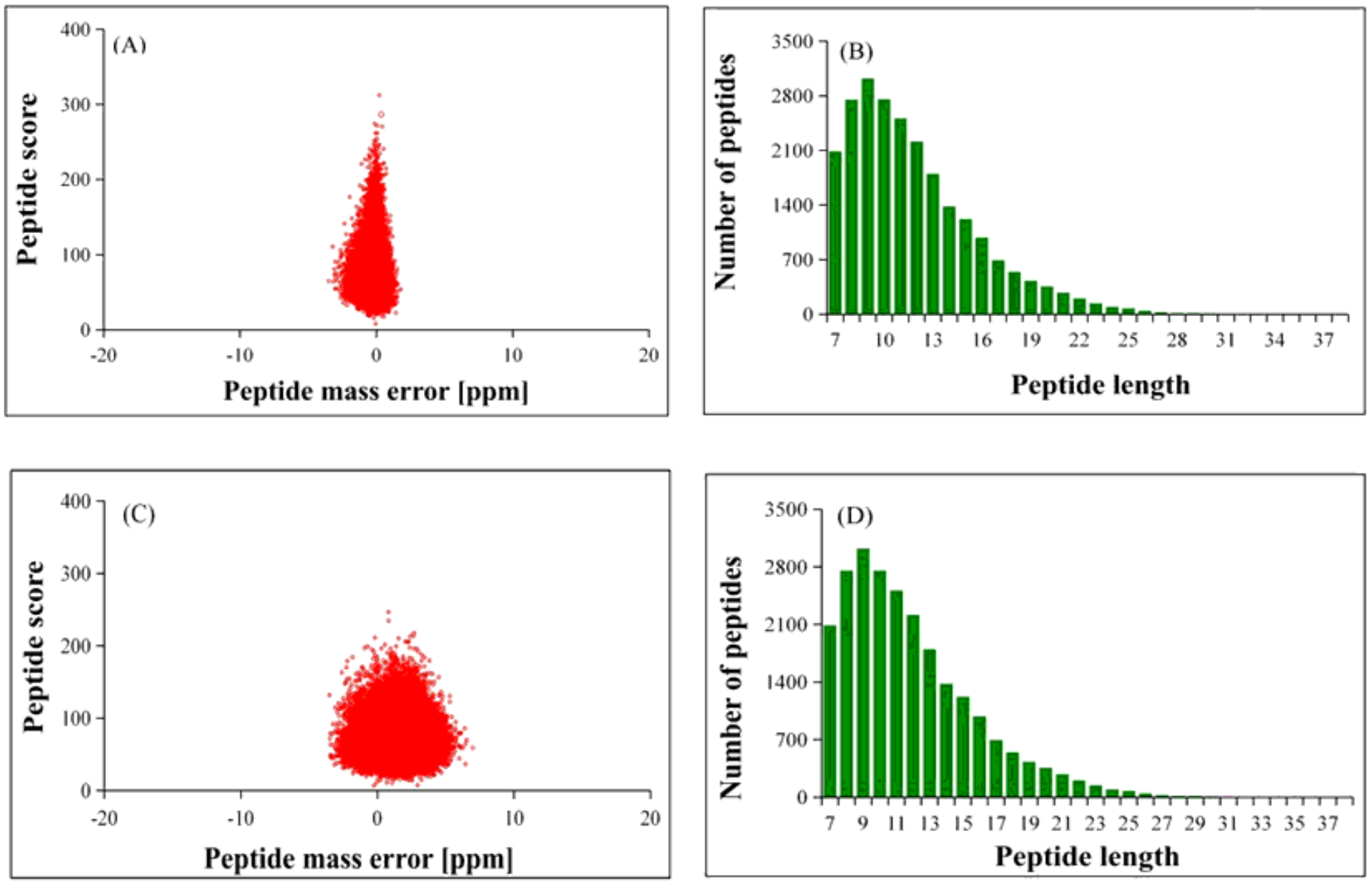

Figure 3

Quality control test results of mass spectrometry data; Where (A) and (C) represent the peptide mass error of $E$. urophylla $\times E$. grandis and D. odorifera, $(A)$ and $(C)$ represent the peptide length of $E$. urophylla $\times E$. grandis and $\mathrm{D}$. odorifera 


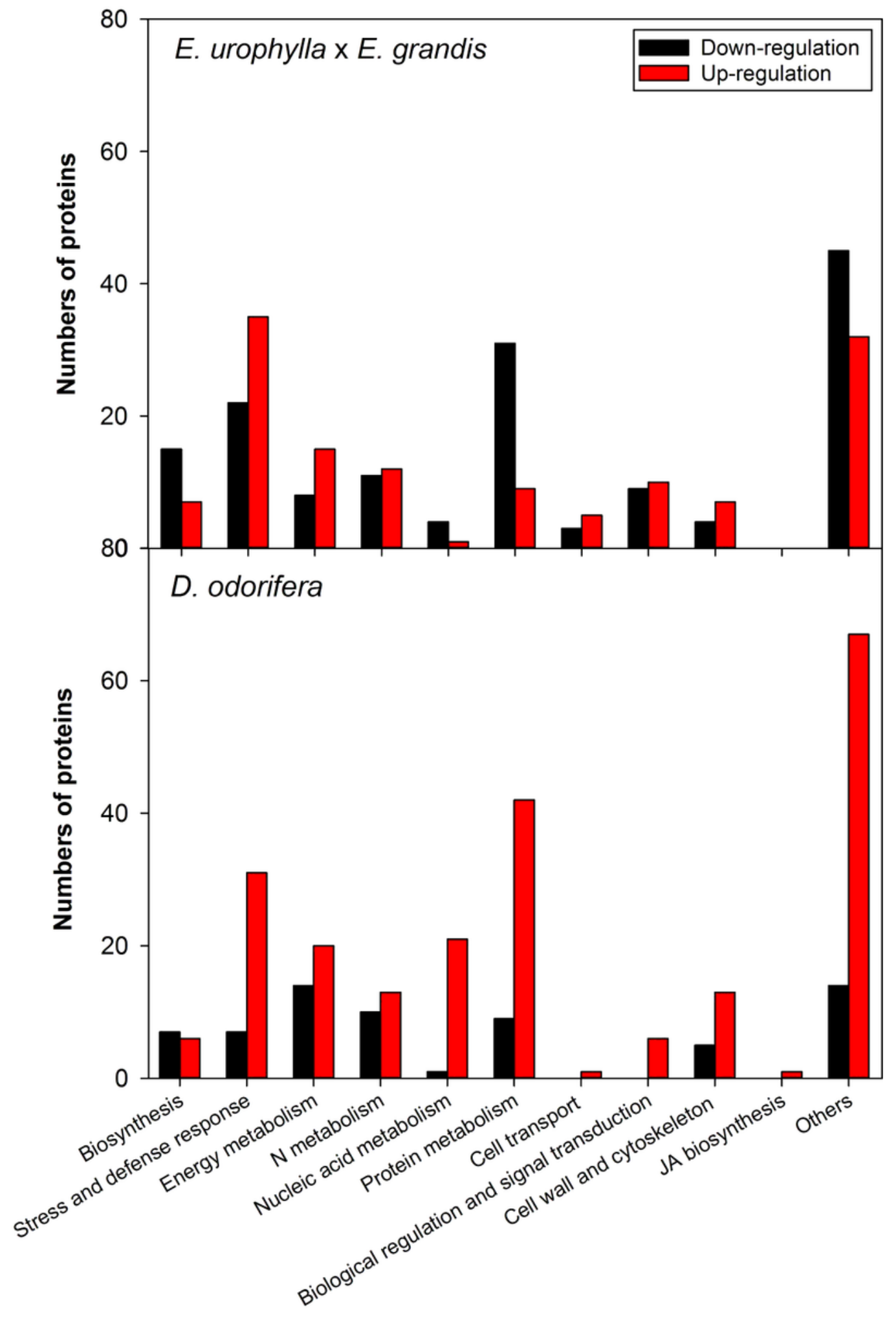

Figure 4

Functional category distribution of the identified proteins in E. urophylla $\times$ E. grandis and D. odorifera roots 


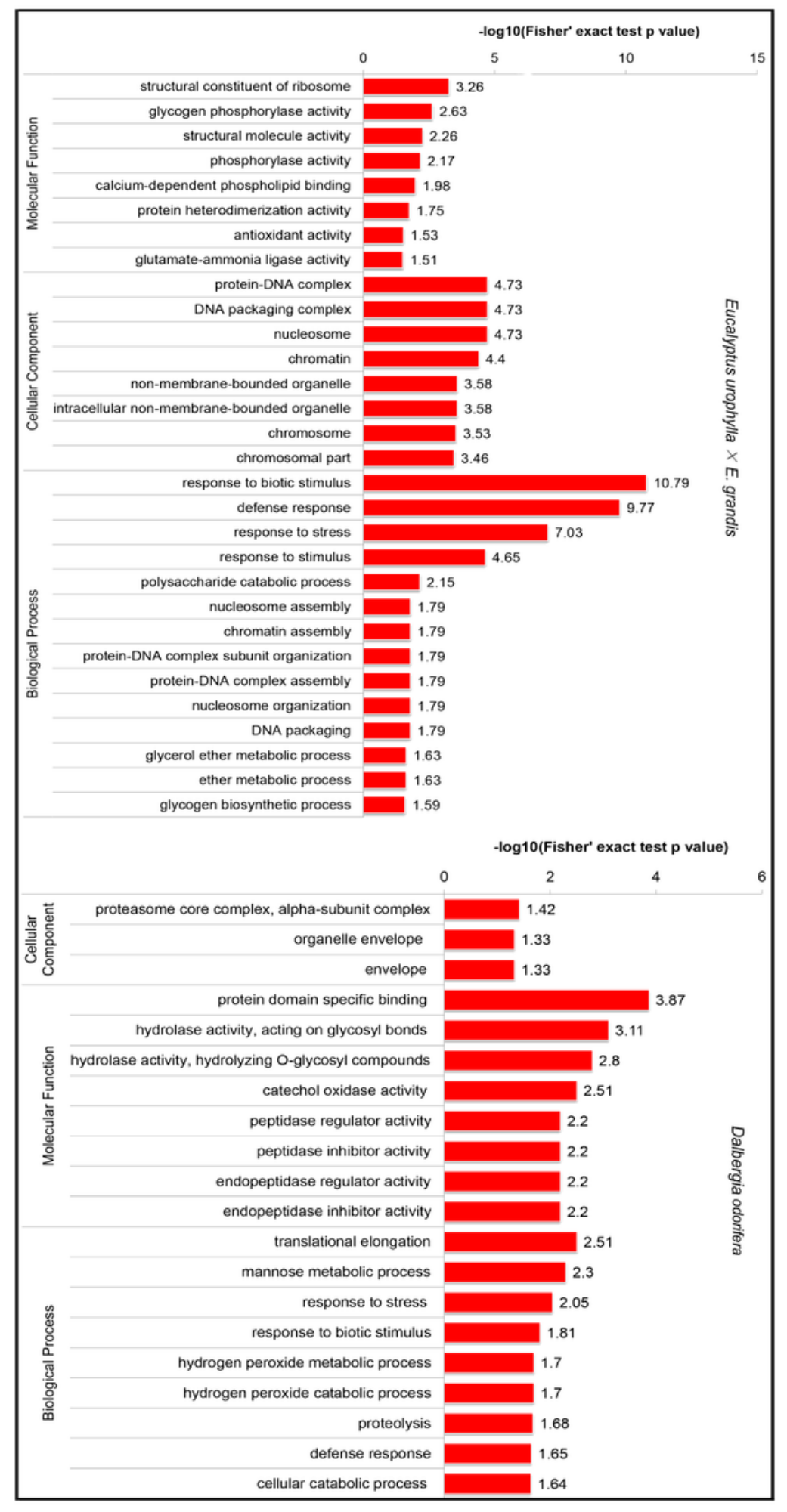

Figure 5

GO-based enrichment analysis of all the proteins from E. urophylla $\times$ E. grandis and D. odorifera 


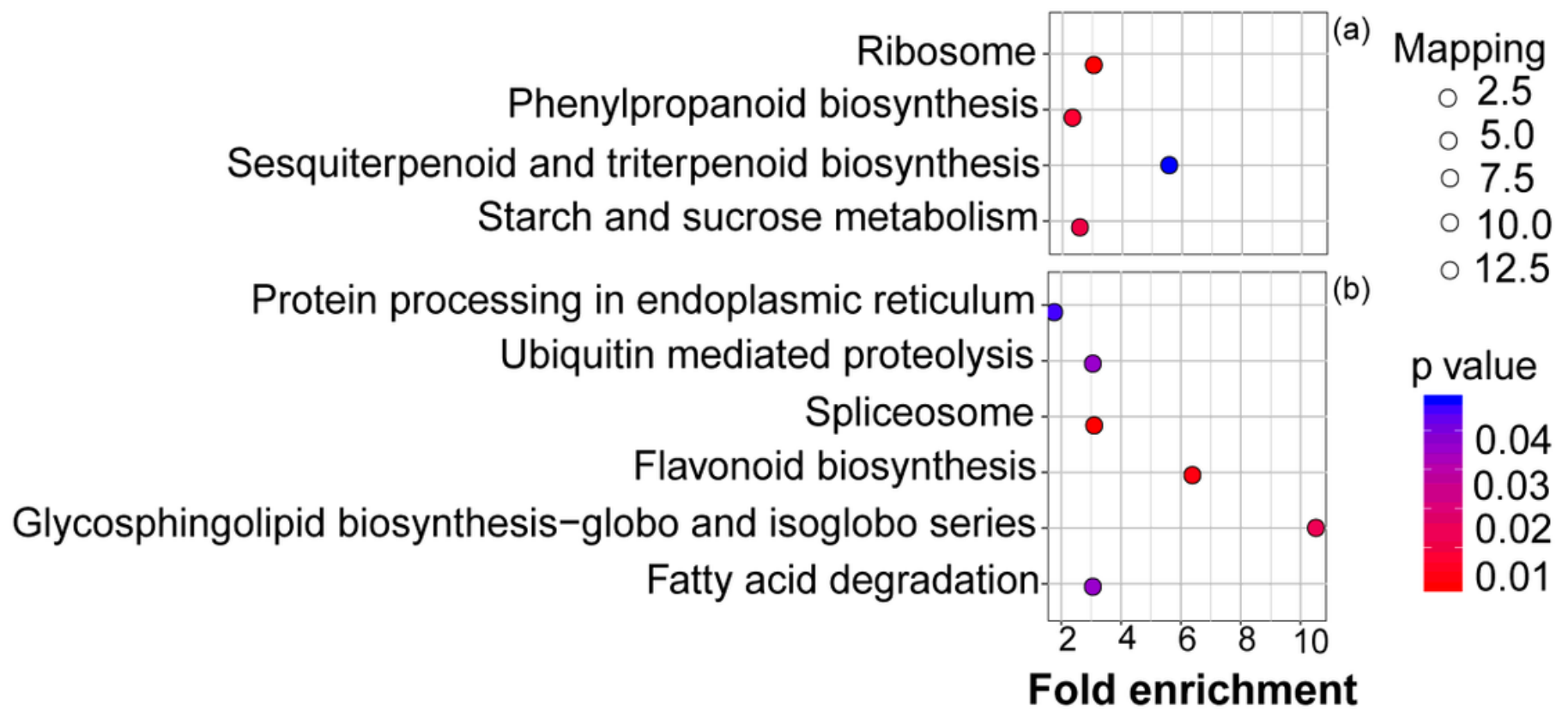

Figure 6

Differential proteins involved in KEGG pathways of E. urophylla $\times$ E. grandis (a) and D. odorifera (b) 

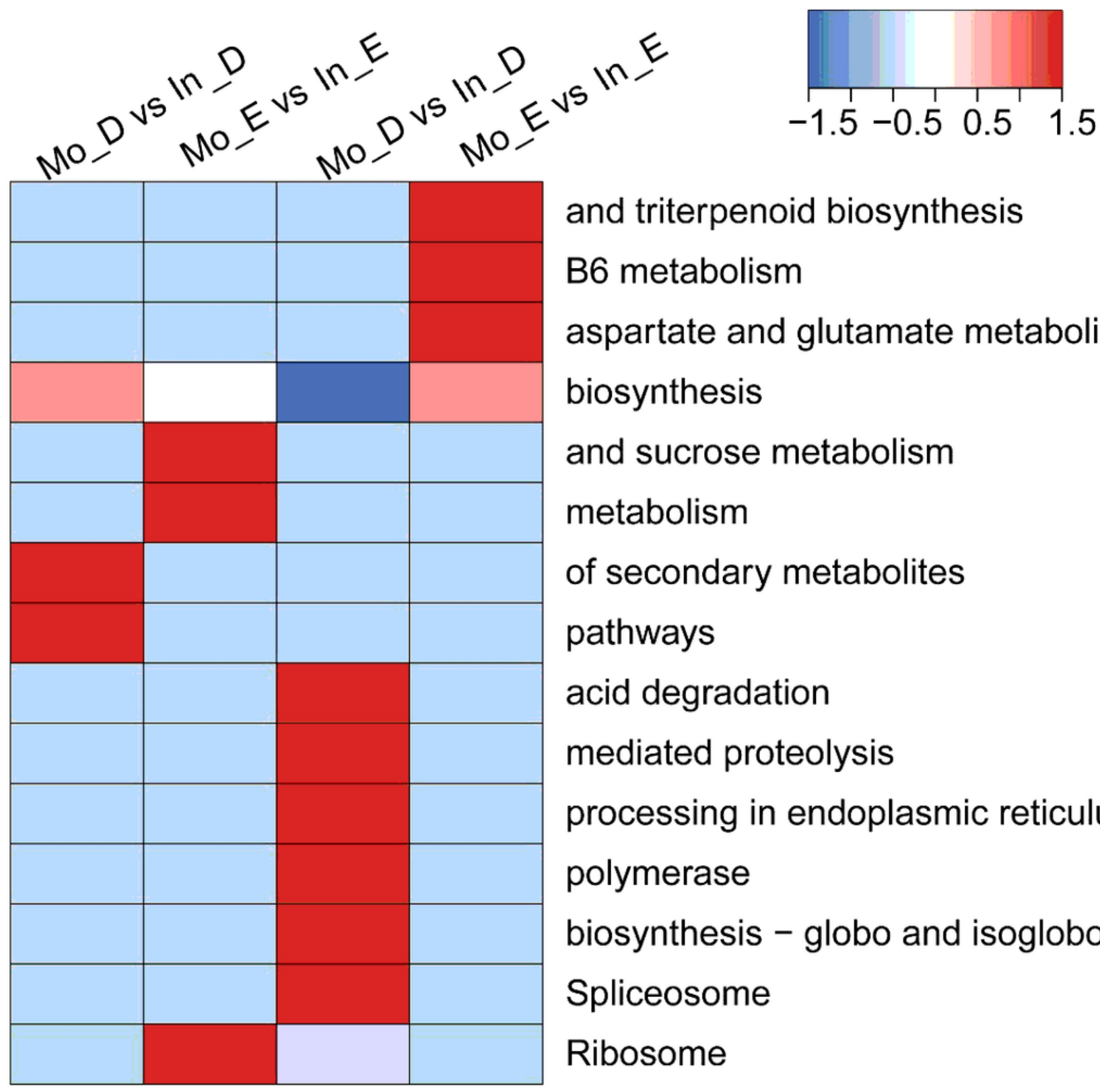

and triterpenoid biosynthesis

B6 metabolism

aspartate and glutamate metabolism

biosynthesis

and sucrose metabolism

metabolism

of secondary metabolites

pathways

acid degradation

mediated proteolysis

processing in endoplasmic reticulum

polymerase

biosynthesis - globo and isoglobo series

Spliceosome

Ribosome

Figure 7

KEGG pathway enrichment-based clustering analysis of all the identified proteins 

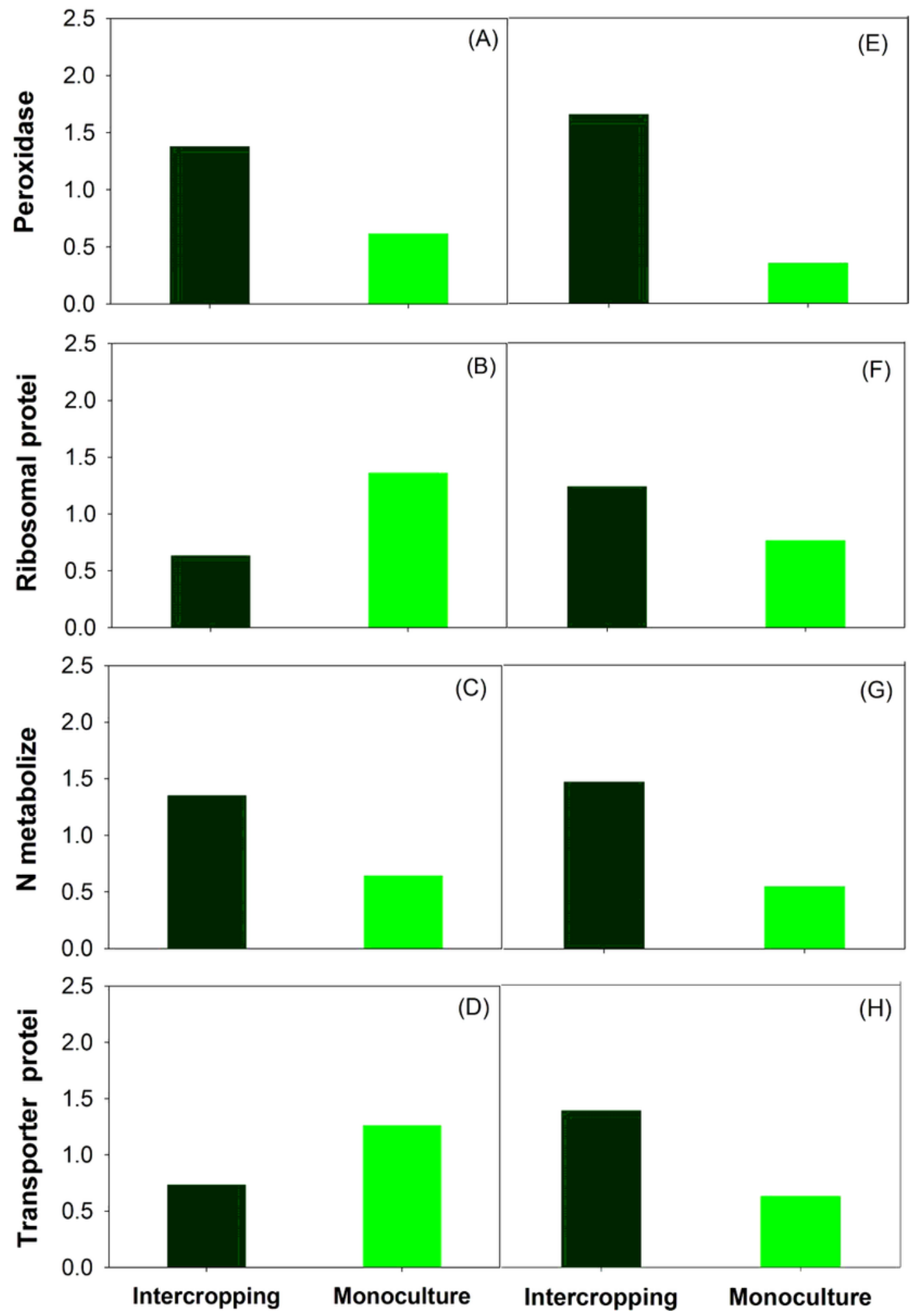

Figure 8

Relative expression levels of PRM from E. urophylla $\times$ E. grandis $(A-D)$ and D. odorifera $(E-H)$ roots.

\section{Supplementary Files}

This is a list of supplementary files associated with this preprint. Click to download. 
- Schedule1.xIsx

- Schedule2.xIsx

Page $30 / 30$ 